\title{
INNOVATION SYSTEMS IN THE TERMS OF SCHUMPETERIAN CREATIVE DESTRUCTION
}

\author{
Robert Ciborowski \\ University of Bialystok \\ Economics and Management Faculty \\ 63 Warszawska str., Bialystok, Poland 15067 \\ cibor67@gmail.com
}

\begin{abstract}
'Creative destruction' is one of the most important analytical tools, taking into consideration both the economic and sociological characteristics of capitalist society. According to Schumpeter, in the long term, evolution gives rise to economic development resulting from batches of innovative solutions, leading to improvements in the standard of living.

The innovation activity of firms is based on supply-side factors, hence it is large enterprises that excel in innovation since they strive to achieve a monopoly market position and above-average profits.

Schumpeter attempts to combine two elements: the spread of monopolies and the continuation of economic development, both occurring through innovation, which is far more important than price competition. The Schumpeterian 'creative destruction' permeates the main aspects of macroeconomic activity, not only in the long term, but also in the area of economic fluctuations, structural changes, or the functioning of markets. As a result, it becomes a factor determining changes in the economic order.
\end{abstract}

Keywords: innovation, creative destruction, Schumpeter.

\section{Introduction}

The recent growing interest in the role of innovation in economic development has prompted many theoreticians to return to the work of Joseph Schumpeter. His conception of economic and social evolution, which defines the nature and extent of the impact of innovation, has lately become one of the most frequently applied theorems of the economic sciences. The presentation of the evolution of socio-economic systems and the factors which shape them makes it possible to explain the formation and functioning of an economic order in a more analytical way.

The purpose of this paper is to characterize the process of 'creative destruction' against the theoretical assumptions of Schumpeter's work and to indicate its main constituents that influence the performance of innovation systems.

\section{Literature review}

The problem of creative destruction and its role in economy was analyzed in few aspects: as a process of economic cycles [1-5], element of economic crises [6-8] and as a part of innovation development $[1,9]$.

In Schumpeter's creative destruction, the ability and initiative of entrepreneurs, drawing upon the discoveries of scientists and inventors, create entirely new opportunities for investment, growth and employment.

Schumpeter suggested that economic cycles are the consequence of innovation, but also that innovative activities and innovative organizations are re-shaped by economic crises [10]. In particular, we interpret the canonical debate between the two models elaborated by the young and the old Schumpeter in the following way [11, 12]. Schumpeter described development as a historical process of structural changes, substantially driven by the innovation.

\section{The aim and objectives of the study}

The object of research is the creative destruction process and its influence on innovation process.

The aim is to analyze of creative destruction as a source of innovation systems reintegration.

To achieve this goal the following objectives:

1. Analysis of the literature about creative destruction. 
2. Extensive interpretation of the relation between creative destruction and innovation process.

3. The assessment of the innovation influence on the innovation systems in the terms of creative destruction.

\section{Materials and methods of research}

The main method of research is a literature review by identifying the main authors, articles, theories and findings in that area. The next step was a qualitative analysis of the theory in the aspect of research questions.

Conclusions were based on the verbal logic analysis which allows find and interpret the relation between the creative destruction and innovation systems.

\section{5. 'Creative destruction': the nature of the process}

The activity of modern enterprises is, to a large degree, based on the innate creativity of individuals who continually discover new objectives, tools or knowledge, and endeavour to find a way to apply them in economic practice. This approach is closely associated with the conditions of 'creative destruction', a phenomenon that provides impetus to the development of markets. 'Creative destruction' clearly harks back to German Romantic philosophy, which glorified the power and delight of human creation (Schopfungskraft). It also reflects the Renaissance idea that man was created in the image and likeness of God, and emphasizes the joyful duty to be an inventor [13]. In the 20th century, the same idea was used in Schumpeter's conception of an entrepreneur (routine breaker), who becomes an innovator motivated not merely by a desire to gain profit, but also by an intrinsic need to act [3]. Being an entrepreneur entails being capable of conducting efficient business activity. Entrepreneurship means a natural capacity of human beings to respect and discover the opportunities for profit that appear on the market, and to take advantage of them [14-17] or, in other words, people's ability to generate and develop new economic strategies.

Also Zombart's writings include references to 'creative destruction', as well as to Goethe, when characterizing the phenomenon of creation. Many themes present in the German economics of that era are concerned with the idea of creation and the need for a holistic approach [18], which, according to Helander, allows one to call it 'Faustian economics'. To a significant extent, these considerations can be also applied to modern entrepreneurship and innovation.

Schumpeter's concept draws from the German economic thought of the 19th and 20th centuries, i. e. from before the Methodenstreit period. Besides, certain affinities can be noticed between the ideas of Schumpeter and those of Marx, Schmoller, Simon, and the aforementioned Zombart.

In the The Communist Manifesto, Marx and Engels specify the most important characteristic of the capitalist economy in the following manner: 'The bourgeoisie cannot exist without constantly revolutionizing the instruments of production, and thereby the relations of production, and with them the whole relations of society. Conservation of the old modes of production in unaltered form was, on the contrary, the first condition of existence for all earlier industrial classes. Constant revolutionizing of production, uninterrupted disturbance of all social conditions, everlasting uncertainty and agitation distinguish the bourgeois epoch from all earlier ones. ' [19].

Although Schumpeter was in entire disagreement as to the sources and role of revenue and ownership in capitalism, it was from Marx that he derived his theory of the erosion of profit margins during diffusion of innovations. However, in the later period he sided with Menger and his Methodenstreit, as well as repeatedly, throughout his academic career, acknowledged Walras' Law [11].

Schmoller engaged in a long-standing methodological debate with Menger, contesting the abstract-deductive methods of inquiry advocated by the Austrians, and proposing instead the more holistic, empirical and inductive approach of the historical school. He strongly emphasized the necessity to comprehend and heed the historical and social context of the economic histories of particular nations. But at the same time, he questioned the existence of objective economic principles, based on logic and on a mechanistic approach to economic phenomena.

According to Simon, the threat of bankruptcy and the will to keep business running lead entrepreneurs to improve their abilities to cope with hostile conditions. In his theoretical model, companies use their acquired skills as long as it helps them to maintain satisfactory results. Market 
competition triggers the process of innovation or imitation, which forces enterprises to seek new skills. If these prove efficient, a destruction of the old organizational system ensues, and a new one emerges.

Schumpeter disagreed with the Schmoller's and Simon's concepts. For him, creation (innovation) was an independent process, not one necessitated by deficits or by external factors. Innovation makes it possible to create a new system of abilities by destroying the existing one. 'Capitalism [...] is by nature a form or method of economic change and not only never is, but never can be stationary' [9].

The central facet of Schumpeterian 'creative destruction', a process strictly connected with the nature of market mechanism, is his discussion of forms of competition capable of a definitive improvement of an economy, both in the quantitative and qualitative sense. It is the entrepreneurial process that constitutes this explosive force which can, because of its sheer creativity, unsettle the existing order. At its heart is the technological advantage, stemming primarily from the internal potential of a company, above all the potential to conduct R\&D activity. This is why, according to Schumpeter, among enterprises more likely to innovate are large companies, monopolists, as well as those which have higher innovation potentials [9].

New technological phenomena are born of dynamic, innovative competition, and not a static price-based rivalry. Simple price competition merely results in cheaper consumer goods. Meanwhile, non-price mechanisms guarantee greater usefulness of future products and their better utilization. This allows for the co-existence on the market of a mixture of cheap, technologically inferior goods and more expensive, but also more innovative ones. This kind of competition outlines the development paths for enterprises, which must strive towards qualitative changes and possess a potential for creating new solutions, in terms of technology, organization or marketing.

Schumpeter also pays attention to the lack of economic equilibrium, directly referring to the work of Walras. When no economic data undergo change but are perfectly predicted by the market entities, stationary circular flow occurs, and all activity happens automatically. No one gains any additional profits or suffers losses, because they are perfectly capable of adapting to the conditions governing the market. But the real world is different, and thus business entities have to continually adjust to new circumstances. This takes place through competition and innovation, when these two annihilate the existing state and give rise to new economic structures.

The steady state resulted from the system of components, which form the circular flow and trigger development processes, which always have an evolutionary origin. The steady state is influenced by a number of factors that can be divided into two groups:

1) external factors, non-social in nature, such as: the natural environment in which an economy operates, as well as economic conditions: e. g. the legal or political system, historic events and processes;

2) internal factors associated with changes taking place on the market; on the demand side, these include the changing preferences of purchasers, on the supply side: the changes regarding production resources.

As Schumpeter points out, the above factors are not capable of stimulating development, but can merely help to maintain the circular flow. Development is possible only thanks to incremental changes consisting in new ways of applying production resources (innovation).

Economic processes fall into three separate categories: circular flow processes, development processes, and the processes which interfere in this development (cyclical and structural events). Competition it is all about innovation, i. e. a rivalry between novelties and older products (or processes). New offers appear at bargain prices because costs decrease. Entire markets function thanks to constant innovation-driven competition. Innovation leads to a certain kind of monopoly, but this monopoly is dynamic (transient).

Under free economic competition, propensity for innovation becomes weaker. The bulk of what we call economic progress is incompatible with perfect competition. If it was possible to imitate the majority of products, most innovators would lose the motivation to act [20].The obstacles that hinder development are not a consequence of monopoly, but of inertia or inability to overcome risks. Therefore, in a 'trustified' economy, they are not greater than in free market capitalism.

Schumpeter combines the formula of 'creative destruction' with an analytical model of economic evolution formulated in Business Cycles, according to which, the evolution of acquired skills can drive an economy to one of the following states [6]: 
- initial equilibrium: its starting point is a system relying on routine behaviour; the system reaches an equilibrium which allows its participants to operate in the market;

- innovation: the initial equilibrium is upset when a group of innovators commences their activity; this improves the economic situation, but the stream of innovations gradually dries up since the innovative skills become depleted and new solutions are increasingly more difficult to implement in the conditions of systemic disequilibrium;

- renewed equilibrium achieved through 'creative destruction': the innovative impulse is insufficient to benefit the economy and the process of fierce market competition begins, leading to the closure of some companies and leaving others strengthened and equipped with additional skills necessary for survival in the economic system; all this leads to the establishment of a new, better routine system;

- economic evolution under the conditions of 'creative destruction': the system changes, shaped by the newly-acquired skills of its players; new circumstances emerge, and temporary disturbances result from innovative behaviours; this process creates socio-political reactions which may have a bearing on the functioning of the system in the future.

It can be said, therefore, that there are two aspects to Schumpeterian 'creative destruction'. First, by means of innovation, 'creative destruction' causes a selection of firms depending on their skills. Second, it determines the extent of innovative activity of competing enterprises.

'Creative destruction' can be seen as a 'Darwinian process', involving various kinds of conflicts between the participants [21], or as an opportunity to modify the business millieu (Lamarck's theory) by providing expenditure on R\&D or through marketing activity [6]. 'Many companies must collapse as a result of creative destruction, but if they withstand the storm, they can survive. They will survive, provided they lose as few production functions as possible and strive to maintain employment' [9].

All the above demonstrates that there exist factors which can be used to counter the cumulative effect of destruction, both within enterprises and in state economic policy. Although Schumpeter was inspired by the theories proposed by Lamarck, his concept is frequently presented as a Darwinian model. This is because of its greater simplicity and practicability [6].

The concept of 'creative destruction' can be perceived as a major analytical tool, well adapted to the economic and sociological characteristics of a capitalist society. Schumpeter believed that, in the long term, the economic evolution contributes to an increased standard of living. It is essential, however, what socio-political reactions are evoked throughout its course. These reactions are inherent in capitalism as a driving force of human endeavour [20]. Innovations represent a kind of a 'rationalist attitude' which dismisses the reliance on sacred institutions and the predictability of social life. Capitalism always contains elements of unpredictability and instability, and that is why it gives rise to a spontaneous economic order [6].

\section{Innovation as factor of change in economic systems}

In both national and global economies, change and development are inherently associated with innovation processes, which alter the nature and dynamics of economic progress by creating new economic structures.

Schumpeter pointed out the long-term influence of innovation on economic development by analyzing various historic periods in which different types of innovation were prevalent. The period 1775-1845 was marked by the dominance of water power, textiles and iron, the years 1845-1900 were the time of steam power, rail transportation and steel, while 1900-1950 - of electricity, chemicals and the internal-combustion engine. The period 1950-1990 saw a dynamic development of the petrochemical industry, electronics and aviation. The current wave of innovation, initiated in the USA at the end of the 1980 s, is driven by new solutions in the fields of digital networking, software and integrated transmission of information via the new media (and also by the impulses triggered by these changes in other areas, such as biotechnology or materials engineering).

The particular periods when groundbreaking innovations occurred caused a significant acceleration of economic development, combined with noticeable transformation of economic systems. As a result, new economic orders were established: a reflection of the technological change. 
At the initial stage of industrial development, technological progress was endogenous, as it took place in material production and was limited to minor routine improvements. In the second half of the 19th century, innovations increasingly started to take an exogenous form, i. e. they relied on the R\&D sector operating outside enterprises. After World War II, the R\&D field began to take a distinct shape, becoming a new branch of national economies - one where technological innovations were generated for industry, agriculture, services, medicine, and environmental protection.

The modern wave of innovation has led to significant qualitative changes in the world economy. The consumption of material and energy resources in industrial production has decreased .For the last two decades global production growth rate has been higher than the rate at which resources and energy are used. This means that economic growth happens under the conditions of negative income elasticity of demand for natural raw materials and energy resources, which leads to lower demand for these goods in the global economy, thus undermining the income of countries which specialize in exporting them.

Thanks to technology diffusion, an equalization of technical capabilities is taking place in enterprises located in different countries, which results in increasing technological parity. At the national level, a similar tendency can be observed, referred to as technological convergence, or 'catch-up'. In the process of technology diffusion, a key role is played by transnational corporations, which achieve it through a geographical integration of dispersed R\&D functions/operations and a subordination of these functions to the global strategies of their mother companies.

The last decade of research into the nature and causes of global economic growth has confirmed that technical 'catch-up' and increased productivity are not autonomous processes, but depend on tangible and intangible investment in education, $R \& D$, and related activity [22, 23]. These factors have become the foundation for successful narrowing of the technological and productivity gaps by some developing countries. However, not all developing economies have succeeded in the same way, because of lack of automatism and stability in international diffusion of innovation $[24,25]$. The tangible factors used for economic development are limited in their scope of action, which lowers their effectiveness. Core knowledge is broadened by experience, attempts, side effects, learning-by-doing, and routine learning [26], to spread subsequently across enterprises by means of training courses, new activities, experimental research and trials. This leads to differences in technical accumulation and further to technology gaps which define particular levels of economic development.

As regards the influence of innovation on economic systems, Schumpeter's most valuable legacy is his analysis of the role of monopolist companies in innovation processes (Schumpeter's Theorem). At the early stages of the technological revolution, many small firms compete with one another to achieve the monopoly and above-average profits. Schumpeterian theory of 'bandwagon' effects points out that, with time, the benefits of this rivalry are eroded as new entrepreneurs enter the market, gain the upper hand, and frequently take over the market leadership. In the later period of intense diffusion, these benefits allow companies to achieve competitive advantages, increase the number of internal innovations or the volume of R\&D expenditure (as it was in the case with Microsoft) [7, 8].

This style of competition among firms strengthens the importance of monopolies, which achieve an innovative advantage, paving the way for further technological development. This is at odds with the claim that monopolist companies hamper innovation or efficiency growth. Schumpeter attaches great importance to the management of innovation on a competitive market $[27,28]$.

The destructive nature of innovation-based competition, leading to the bankruptcy of firms which fail to keep up with technological changes is the main premise of Schumpeterian analysis. Two categories of innovation processes can be distinguished:

- conservative, typical of experienced companies;

- disruptive, usually occurring in firms that are new in the market.

Profitability, which is the main factor that drives innovation, is seen differently by small firms than by large corporations. Therefore, interdependence exists between innovation and the structure of the market, as it is manifested in the following two hypotheses concerning innovation: 
1) the traditional hypothesis holds that the free market is more conducive to innovation,

2) the Schumpeterian one, which assumes that an oligopoly structure is more favourable since it commands more efficient resources;

To assess the degree of market monopolization, it is necessary to select an appropriate measuring strategy. Should the structure of a market be measured as the degree of concentration? Is innovation always a result of $\mathrm{R} \& \mathrm{D}$ activity?

Schumpeter's theory attempts to combine two notable facts: the spread of monopolies and the continuation of economic development. This allows him to use the category of 'indirect competition' through innovation, which is far more important than price competition. The above formula stabilizes the development of trustified capitalism by creating conditions for the establishment of new innovation companies [29-31].

New firms exert greater competitive pressure by setting new trends for technological progress. Disruptive innovations appear and are subsequently streamlined. This changes the production structure in a fundamental way, leading to new market order. Generating a disruptive innovation, an enterprise defines a new boundary of improvement, which must be accepted by consumers. A new trajectory of improvement is set, allowing for producing new products for the top customer segment. Consequently, the quality of products becomes higher.

Nowadays, this approach is reflected in the concept of 'national innovation systems' [32], which shapes the structure and evolution of economies via innovation.

Analysis of particular enterprises or economies demonstrates that each of them is in a different, specific innovation situation. This means that innovation systems which influence the changes of entire economies and their competitive positions also operate in varying conditions. Besides, the external circumstances faced by these systems are also unique, that leads them to adopt a more international character. The combination of all the factors and determinants causes the innovation systems to undergo constant changes and transformations.

The transformations can be divided into the following stages:

1) disintegration: a dissolution and division of the existing systems; organizational and functional restructuring - consolidation of those elements of old systems which can be adapted to new requirements; emergence of new players and new rules, both in terms of politics and economy (privatization, entrepreneurship, direct foreign investment);

2) reintegration: changes in business models stemming from the fact that R\&D shifts towards a greater significance of innovation activity (technology transfer, diffusion, adaptation); reintegration of the participants as well as research and technology systems;

3) development: formation of new systems as a conjunction of participants and their activities; whether this stage is reached depends on the ability to establish a code of functioning for the system's constituents; at this stage the objective is to achieve a relative stability of the dynamic relations within and outside the system.

The differences between innovation systems are less dependent on internal factors than on the manner of functioning of their immediate environment. Consolidation and development of innovative activity are impossible without political and economic stability, or the openness of markets. Nevertheless, in a globalized world, it is difficult to assess which elements of the systems are the most viable and promising. Most frequently, this depends on the participants of the systems (i.e. enterprises), their innovativeness, technology transfer, and on their future competitive position in international markets.

Having identified the structural and institutional determinants of the formation of innovation systems, it is possible to indicate their major segments, which include:

- companies and their innovative capacities encompassing vertical ties with suppliers and purchasers;

- universities and public R\&D laboratories; their potential for creating general knowledge, educational mission and ability to respond to demand from business entities;

- economic policy oriented towards educating the labour force, ensuring a climate favourable to development, and enhancing trust in the legal and financial institutions. 
The particular components of innovation systems are shaped by a number of internal and external factors which can boost or impair the innovative capacity. In many cases, it is crucial that an innovative potential is generated, which, according to Schumpeter, can either arise from a monopoly or be created through the economic policy of the state.

Large corporations have superior financial and technological resources for creating innovation. With public approval, monopolies develop innovations which benefit society as a whole. If the participation of large companies in innovation processes is limited, there appears a need to build internal liaisons among various entities in order to achieve a desirable technological standard.

Moving from the phase when innovation is carried out by new entities to that when it is 'embodied' in new enterprises has an accelerating effect on development processes. This is an evolutionary process, whose main stimulus consists in new technologies. Innovations cause an implosion of old economic structures and engender new ones. They arrive in clusters, or waves, alternating with periods of relative calm. The process, however, is continuous as there is always either a time of revolution or a period when the outcomes of the resolution are absorbed and consumed, leading to a new business cycle.

The Schumpeterian 'creative destruction' permeates the basic aspects of macroeconomic activity, not only in the long term, but also in the area of economic fluctuations, structural changes, or the functioning of markets. At the microeconomic level, it denotes countless decisions concerning the creation and destruction of a certain order of production. The decisions are often comprehensive and regard both strategic and technological issues. Their efficiency depends not only on managerial skills, but also on the type and range of institutional mechanisms. The failure of this kind of process has numerous macroeconomic implications which interact with the course of 'creative destruction'. There are several obstacles to a smooth progress towards new production concepts. They comprise natural factors, originating from the complexity of transactional processes, and man-made factors: erroneous economic ideas, inappropriate selection of instruments for attaining social objectives, institutional constraints, cyclical changes, or the flexibility of economies. This allows one to explain such economic processes as unemployment, investment or salaries.

\section{Conclusions}

Although the notion of 'creative destruction' and its significance are acknowledged and approved by economists, it is not widely and universally known. As a result, Schumpeter's achievements cannot be fully employed in the various areas of modern economies (economic policy, law). Only very seldom premises of 'creative destruction' are applied to analysis of contemporary determinants of economic growth.

The Schumpeterian 'creative destruction' process demonstrates that innovative advantage is the main source of economic growth and development. The ability to achieve this kind of advantage is possible thanks to the stepping up of innovation activities by gaining a monopolist position. Large companies are the most efficient creators of innovation, being able to incur substantial expenditure on R\&D.

Those economies which are open to disruptive innovation and are ready to embrace 'creative destruction' have better opportunities for a dynamic economic development. This happens through the changes in production structure and the creation of new economic order based on innovating companies. Schumpeter saw changes in the capitalist economy as an intermittent rather than continuous process. It results from the novelty of applied technological solutions and the consequent destruction of the current economic order.

Due to competitive pressure, innovations appear and the process of their imitation begins. New solutions are diffused more and more widely, bringing about an economic boom. In the long term, the extraordinary gains vanish and the interest in a given innovation gradually declines. The economy enters a crisis mode and the need for a new breakthrough arises. This takes the form of a business cycle based on technological shocks. 
To sum up, from the point of view of the dynamics and efficiency of development processes, 'creative destruction' is a beneficial phenomenon. It contributes to the modernization of economies, helps to gain technological advantages, and ushers in such structural changes which reflect the increasing level of innovation

\section{References}

[1] Fagerberg, J. (1988). International Competitiveness. The Economic Journal, 98(391), 355. doi:10.2307/2233372

[2] Mueller, K. (1999). Perspective of Market Based Stimulation of Technology Transfer in the Transitive Economies of Middle Europe. Industry as a Stimulator of Technology Transfer, Warszawa, Białystok.

[3] Rosegger, G. (1986). The Economics of Production and Innovation. An Industrial Perspective. Oxford: Pergamon Press.

[4] Rosenberg, N. (1983). Inside the black box. doi:10.1017/cbo9780511611940

[5] Rosenberg, H., Schumpeter, J. (1940). Business Cycles: A Theoretical, Historical, and Statistical Analysis of the Capitalist Process. The American Historical Review, 46(1), 96. doi:10.2307/ 1839798

[6] Andersen, E. S., Dahl, M. S., Lundvall, B. A., Reichstein, T., (2006). Schumpeter's process of creative destruction and the Scandinavian systems: a tale of two effects. Papers for the DRUID conference, 25 .

[7] Freeman, C., Louçã, F. (2002). As Time Goes By. doi:10.1093/0199251053.001.0001

[8] Freeman, C., Soete, L. (1973). The Economics of Industrial Innovation. London: Penguin Books, 484

[9] Solow, R. M. (1957). Technical Change and the Aggregate Production Function. The Review of Economics and Statistics, 39(3), 312. doi:10.2307/1926047

[10] Kundera, E. (1996). Doktryna socjalistów z katedry. Uniwersytet Wrocławski.

[11] Gordon, R. J. (2000). Does the "New Economy" Measure up to the Great Inventions of the Past? Journal of Economic Perspectives, 14(4), 49-74. doi:10.1257/jep.14.4.49

[12] Kirzner, I. (1979). Perception, Opportunity and Profit: Study in the Theory of Entrepreneurship. University of Chicago.

[13] Rogers, E. (1962). Diffusion of innovations. Glencoe: Free Press, 453

[14] Kuznets, S. (1930). Secular Movements in Production and Prices. Boston, Houghton Mifflin, 536 .

[15] Łukaszewicz, A. (2001). Nauka, innowacje, technologia XX wieku. Refleksje społeczno-ekonomiczne. Ekonomia, 1.

[16] Lundvall, B. A. (1992). National Systems of Innovation: Towards a Theory of Innovation and Interactive Learning. London, Pinter Publishing, 317.

[17] Marks, K., Engels, F. (2007). Manifest Partii komunistyczny. Warszawa, 21.

[18] Schumpeter, J. A. (1995). Kapitalizm, socjalizm, demokracja. Warszawa, PWN.

[19] Mikosik, S. (1993). Teoria rozwoju gospodarczego J. A. Schumpetera. Warszawa, PWN.

[20] Schumpeter, J. A. (1960). Teoria rozwoju gospdoarczego. Warszawa, PWN.

[21] Reinert, H., Reinert, E. S. (n.d.). Creative Destruction in Economics: Nietzsche, Sombart, Schumpeter. The European Heritage in Economics and the Social Sciences, 55-85. doi:10.1007/978-0387-32980-2 4

[22] Freeman, C. (2003). A Schumpeterian Renaissance? SEWPS SPRU, 22.

[23] Freeman, C., Clark, J., Soete, L. (1982). Unemployment and Technical Innovation. a Study of Long Waves and economic Development. London: Pinter. 
[24] Bell, M., Pavitt, K. (1993). Technological Accumulation and Industrial Growth: Contrasts Between Developed and Developing Countries. Industrial and Corporate Change, 2(1), 157-210. doi:10.1093/icc/2.1.157

[25] Christensen, C. M., Raynor, M. E. (2008). Innowacje. Napęd wzrostu. Warszawa: Studio Emka, 328.

[26] Fiedor, B. (1986). Neoklasyczna teoria postępu technicznego próba systematyzacji i krytycznej analizy. Wrocław: Akademia Ekonomiczna.

[27] Diamond, A. M. (2006). Schumpeter's Creative Destruction: A Review of the Evidence. Journal of Private Enterprise, 22 (1).

[28] Dosi, G., Teece, D. J., Chytry, J. (1998). Technology, Organization, and Competitiveness. doi:10.1093/0198290969.001.0001

[29] Phelps, E. S. (1966). Models of Technical Progress and the Golden Rule of Research. The Review of Economic Studies, 33(2), 133. doi:10.2307/2974437

[30] Phillips, A. (1971). Technology and industry structure. Technology and International Trade. Washington: National Academy of Engineering.

[31] Reinert, E., Daastol, A. (1997). Exploring the Genesis of Economic Innovations: The Religious gestalt-switch and the duty to invent as preconditions for economic growth. European Journal of Law and Economics, 4(2/3), 233-283. doi:10.1023/a:1008631410924

[32] McCraw, T. K. (2007). Prophet of Innovation: Joseph Schumpeter and Creative Destruction. Harvard UP, 719. 